\title{
PENGARUH MEDIA JIGSAW PUZZLE TERHADAP MINAT BELAJAR HURUF HIJAIYAH (MENYUSUN KATA BAHASA ARAB) ANAK USIA DINI
}

\author{
Rofik Jalal Rosyanafi, Widya Nusantara, Halimah \\ Universitas Narotama, Univeristas Negeri Surabaya \\ Email: rofik.jalal.rosyanafi@narotama.ac.id,widyanusantara@unesa.ac.id, \\ bundahalimahcantik@gmail.com
}

\begin{abstract}
Kecintaan terhadap agama Islam hendaknya mulai ditanamkan sejak dini. Beragam cara dapat diupayakan, salah satunya dengan menggunakan metode sederhana yakni pengenalan huruf hijaiyah sebagai huruf yang digunakan didalam menyusun kata bahasa Arab yang merupakan bahasa kitab suci dan tuntunan agama umat Islam sedunia. Penelitian bertujuan mengetahui sejauh mana pengaruh media pembelajaran edukatif dalam hal ini berupa jigsaw puzzle terhadap minat belajar huruf hijaiyah anak usia dini kelas B di TK Aisyiyah Bustanul Athfal 6. Pendekatan eksperimen dengan bentuk penelitian pre-eksperimental design adalah metode dalam penelitian ini. Populasi dalam penelitian ini adalah seluruh anak didik kelas B tahun ajaran 2017-2018 yang berjumlah 12 anak. Berdasarkan hasil analisis data diperoleh rata-rata pre-test 15,415 dan rata-rata post-test 32,375. Hasil uji hipotesis menggunakan t-test diperoleh $t_{\text {hitung }}=9,133$ untuk dk $=11$ dan $\alpha=5 \%$ diperoleh $t_{\text {tabel }}$ sebesar 0,69745 yang berarti $t_{\text {hitung }}>t_{\text {tabel }}$, maka Ha diterima. Jadi, dapat disimpulkan bahwa terdapat peningkatan minat belajar peserta didik kelas B TK Aisyiyah Bustanul Athfal 6. Perhitungan besar peningkatan kosakata anak digunakan normalized gain.
\end{abstract}

Key words: Jigsaw Puzzle; Minat Belajar; Huruf Hijaiyah

\section{A. PENDAHULUAN}

Pendidikan Agama Islam menurut Abdul Majid, dkk (2005:130), adalah upaya sadar dan terencana dalam menyiapkan peserta didik untuk mengenal, memahami, menghayati, hingga mengimani, ajaran agama Islam, dibarengi dengan tuntunan untuk menghormati penganut agama lain dalam hubungannya dengan kerukunan antar umat beragama hingga terwujud kesatuan dan persatuan bangsa. Pendidikan agama hendaknya mulai ditanamkan sejak usia dini dalam upaya mencetak generasi remaja yang unggul tidak hanya pada aspek intelektualitas namun juga pada aspek moral. Hal tersebut dirasa sangat relevan terutama bilamana kita berkaca pada beragam permasalahan yang melanda generasi muda saat ini seperti kekerasan, narkoba hingga sex bebas.

Pembelajaran yang ada pada lembaga-lembaga pendidikan anak usia dini (PAUD), menjadi sarana yang efektif dalam upaya mengimplementasikan pendidikan agama secara formal selain juga dimungkinkan secara informal seperti didalam lingkup keluarga. Trianto (2011: 25), menjabarkan tujuan PAUD secara khusus, yaitu (1) membangun landasan bagi berkembangnya potensi anak agar menjadi manusia beriman dan bertakwa kepada Tuhan Yang Maha Esa, berakhlak mulia, sehat, berilmu, cakap, kritis, kreatif, inovatif, mandiri, percaya diri, dan menjadi warga negara yang demokratis dan bertanggung jawab, (2) Mengembangkan potensi kecerdasan spiritual, intelektual, emosional, dan sosial anak pada masa emas pertumbuhannya dalam lingkungan bermain yang edukatif dan menyenangkan. Anak usia dini belajar memiliki prinsip salah satunya 
dari yang konkrit ke abstrak, dari yang sederhana ke yang kompleks, dari gerakan ke verbal, dan dari diri sendiri kesosial. Hal tersebut menjadi dasar dalam proses pembelajaran agama pada anak usia dini yang lantas tidak langsung mengusung materi yang berat-berat tentang agama dalam hal ini agama islam, melainkan dapat berangkat dari materi yang ringan dan menyenangkan. Pengenalan bahasa arab melalui huruf hijaiyah menjadi salah satu alternatif materi yang sangat dimungkinkan dapat ditempuh oleh para pendidik PAUD dalam upaya mengenalkan bahasa arab sebagai bahasa baku dalam kitab suci Al-Qur'an.

Huruf hijaiyah sendiri menurut Insan Mandani (2007:7), adalah huruf-huruf yang dipakai dalam bahasa arab. Al- Qur'an menggunakan bahsa arab, Al-Qur'an ditulis dengan huruf Hijaiyah. Jumlah huruf hijaiyah ada 29 buah. Huruf hijaiyah ditulis dan dibaca dari kanan ke kiri. Bentuk huruf hijaiyah berbeda-beda. Beberapa huruf hijaiyah berbentuk sama yang membedakan adalah titiknya. Huruf hijaiyah bertitik satu, dua, atau tiga. Tempat titik juga bisa berbeda, ada yang di atas, di dalam, dan di bawah. Berikut adalah tabel huruf hijaiyah yang sangat dimungkinkan untuk dipelajari dengan menyenangkan oleh anak usia dini diberbagai layanan program PAUD;

Tabel 1.1

Huruf hijaiyah (Arab dan Latin)

\begin{tabular}{|c|c|c|c|c|c|}
\hline No. & Arab & Latin & No & Arab & Latin \\
\hline 1 & 1 & $\mathrm{~A} / \mathrm{a}, \mathrm{I} / \mathrm{i}, \mathrm{U} / \mathrm{u}$ & 16 & $b$ & $T / t$ \\
\hline 2 & 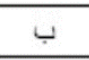 & $\mathrm{B} / \mathrm{b}$ & 17 & b & $\mathrm{Z} / \mathrm{z}$ \\
\hline 3 & ப & $T / t$ & 18 & $\varepsilon$ & '(koma) \\
\hline 4 & ப & $\dot{S} / \dot{s}$ & 19 & $\dot{\varepsilon}$ & $\mathrm{Gh} / \mathrm{gh}$ \\
\hline 5 & ج & $\mathrm{J} / \mathrm{j}$ & 20 & ن & $\mathrm{F} / \mathrm{f}$ \\
\hline 6 & $\tau$ & $\mathrm{H} / \mathrm{h}$ & 21 & في & $\mathrm{Q} / \mathrm{q}$ \\
\hline 7 & $i$ & $\mathrm{Kh} / \mathrm{kh}$ & 22 & 5 & $\mathrm{K} / \mathrm{k}$ \\
\hline 8 & 2 & $\mathrm{D} / \mathrm{d}$ & 23 & $J$ & $\mathrm{~L} / \mathrm{l}$ \\
\hline 9 & $\dot{j}$ & $\dot{Z} / \dot{z}$ & 24 & 3 & $\mathrm{M} / \mathrm{m}$ \\
\hline 10 & J & $R / r$ & 25 & ن & $\mathrm{N} / \mathrm{n}$ \\
\hline
\end{tabular}

\begin{tabular}{|c|c|c|c|c|c|}
\hline 11 & $j$ & $Z / z$ & 26 &, & W/w \\
\hline 12 & $\sim$ & $\mathrm{S} / \mathrm{s}$ & 27 & $\bullet$ & $\mathrm{H} / \mathrm{h}$ \\
\hline 13 & $\sim$ & $\mathrm{Sy} / \mathrm{sy}$ & 28 & $\bullet$ & '(apostrop) \\
\hline 14 & $\omega$ & $\mathrm{S} / \mathrm{s}$ & 29 & $\varsigma$ & $\mathrm{Y} / \mathrm{y}$ \\
\hline 15 & $ض$ & $\mathrm{D} / \mathrm{d}$ & $\cdots$ & $\cdots$ & $\cdots$ \\
\hline
\end{tabular}

Sumber: Surat Keputusan Bersama Menteri Agama dan Menteri P dan K; Nomor 158 tahun 1987 - Nomor: 0543 b/u/1987

Keberadaan media pembelajaran dalam bentuk alat permainan edukatif (APE) dapat dijadikan jembatan yang efektif dalam rangka mengenalkan bahasa arab melalui pengenalan huruf hijaiyah sebagaimana tabel diatas. Alat permainan edukatif (APE) menurut Shofiatun A Rahman (21-22), difungsikan untuk mengembangkan berbagai aspek perkembangan anak usia dini. Aspek-aspek yang dikembangkan meliputi aspek moral, agama, sosial, emosi, bahasa, kognitif, fisik-motorik dan seni. Puzzle merupakan salah satu jenis APE yang menarik untuk diperkenalkan kepada anak PAUD. Puzzle jigsaw sebagai salah jenis puzzle yang dapat dimungkinkan menjadi pilihan alternatif sebagai media belajar anak termasuk dalam mengenalkan huruf hijaiyah. Pada konteks 
penelitian kali ini dengan judul "Pengaruh Media Jigsaw Puzzle terhadap Minat Belajar Huruf Hijaiyah (menyusun kata Bahasa Arab) Anak Usia Dini” diharapkan mampu menganalisis dan mendeskripsikan sejauh mana pengaruh dari puzzle jigsaw terhadap minat belajar anak usia dini dalam konteks huruf hijaiyah bahasa arab.

\section{B. LITERATUR PERMAINAN EDUKATIF}

Pendidikan anak usia dini (PAUD) sebagai lembaga yang penyelenggara pendidikan pra sekolah juga turut memberikan andil yang begitu besar dalam upaya memberikan pondasi religious terhadap anak. National Assosiation Education for Young Children (NAEYC) (dalam Slamet Suyanto, 2005: 6), anak usia dini adalah sekelompok individu yang berada pada rentang usia antara 0-8 tahun. Pada masa ini merupakan masa emas atau golden age, karena anak mengalami pertumbuhan dan perkembangan yang sangat pesat dan tidak tergantikan pada masa mendatang. Pembekalan pendidikan agama pada tingkatan sekolah dasar tidaklah terlambat, namun akan lebih tepat bila semenjak dini sudah ditanamkan kecintaan akan hal-hal yang bernuansa agama, mengingat selain di usia ini merupakan usia emas untuk perkembangannya juga mengacu pada prinsip pembelajaran pada PAUD yang belajarnya adalah bermain. Keberadaan media dalam pembelajaran anak usia dini seperti alat permainan edukatif (APE) juga turut memberikan kemudahan dalam operasional pembelajaran anak usia dini.

Permainan edukatif sebagimana pernah di kemukakan Fathul Mujib dan Nailur Rahmawati (2013:29), adalah permainan yang memiliki unsur mendidik yang didapatkan dari sesuatu yang ada dan melekat serta menjadi bagian dari permainan itu sendiri. Selain itu, permainan juga memberi rangsangan atau respons positif terhadap indra pemainnya. Indra yang dimaksud antara lain pendengaran, penglihatan, suara (berbicara, komunikasi), menulis, daya pikir, keseimbangan kognitif, motorik (keseimbangan gerak, daya tahan, kekuatan, keterampilan, dan ketangkasan), afeksi, serta kekayaan sosial dan spritual (budi pekerti luhur, cinta, kasih sayang, etika, kejujuran, tata krama dan sopan santun, persaingan sehat, serta pengorbanan). Keseimbangan indra inilah yang direncanakan agar mempengaruhi jasmani, nalar, imajinasi, watak dan karakter, sampai tujuan pendewasaan diri. Sebab, watak seseorang akan turut menentukan arah perjalanan hidupnya.

Seiring perkembangannya, beragam jenis alat permainan edukatif dapat kita temukan dengan tentunya mempunyai fungsi dan manfaat yang beragam. Adapun beberapa jenis alat permainan edukatif bila ditinjau penggunaan dengan menyesuaikan pola perkembangan dari anak adalah sebagai berikut: 
Tabel 1.2

Jenis-jenis APE berdasarkan penggunaan dan perkembangan anak

\begin{tabular}{|c|c|c|c|}
\hline No & $\begin{array}{l}\text { Anak } \\
\text { Usia }\end{array}$ & Perkembangan Anak & $\begin{array}{l}\text { Simulasi yang harus } \\
\text { diberikan }\end{array}$ \\
\hline 1. & $\begin{array}{l}5-6 \\
\text { Tahun }\end{array}$ & $\begin{array}{l}\text { a. Mulai tumbuh rasa pecaya } \\
\text { diri dan merasa mampu } \\
\text { mengerjakan sesuatu } \\
\text { b. Minat dan motivasi belajar } \\
\text { semakin meningkat. } \\
\text { c. Rasa bertanggung jawab } \\
\text { semakin meningkat. } \\
\text { d. Senang mengunjungi } \\
\text { rumah temannya } \\
\text { e. Lebih mandiri. } \\
\text { f. Rasa humornya semakin } \\
\text { berkembang. } \\
\text { g. Senang bermain dengan } \\
\text { huruf. } \\
\text { h. Mengenal banyak warna. } \\
\text { i. Memiliki kosakata kurang } \\
\text { lebih } 2000 \text { kata. } \\
\text { j. Mulai menggabungkan } \\
\text { dari fantasi ke realita. } \\
\text { k. Mampu menggunakan } \\
\text { kata sulit. }\end{array}$ & $\begin{array}{l}\text { a. Permainan dengan } \\
\text { mengunting- } \\
\text { gunting } \\
\text { b. Buku-buku cerita. } \\
\text { c. Boneka jari atau } \\
\text { sejenisnya. } \\
\text { d. Kartu angka, } \\
\text { huruf, atau kartu } \\
\text { warna. } \\
\text { e. Permainan dengan } \\
\text { mencocok dan } \\
\text { lain-lain } \\
\text { f. Permainan yang } \\
\text { membentuk dan } \\
\text { mencetak. } \\
\text { g. Permainan yang } \\
\text { membtuhkan } \\
\text { persaingan. }\end{array}$ \\
\hline
\end{tabular}

Dikutip dari Aqib (2011:80).

Adapun jenis-jenis dari APE puzzle bilamana diklasifikasikan pada tempatnya meliputi;

1. Kategori APE diluar ruangan yakni APE yang dimainkan anak untuk bermain bebas sehingga memerlukan tempat yang luas dan lapang. Contohnya seperti tangga pelangi, jungkitan, ayunan, papan luncur dan lain-lain.

2. Kategori APE di dalam ruangan adalah APE jenis manipulatif yakni APE yang dapat dimainkan anak dengan diletakkan di atas meja, dapat dibongkar pasang, dijinjing dan lain-lain Contohnya seperti puzzle, balok bangunan, kotak pos, boneka dan lain-lain Badru Zaman (2007:6-18).

Penggadaan hingga penggunaan APE pun semakin kesini mengalami kemudahan, karena mudah untuk dijumpai toko mainan konvensional maupun online. Puzzle merupakan salah satu APE yang kerap kita temui dan tentunya juga digunakan, yang mana hal ini akan berdampak pada minat peserta didik dalam hal ini anak usia dini.

Puzzle sebagaimana pernah diungkapkan oleh Febri Hidayat (2013: 2), adalah permainan yang menarik bagi anak usia dini karena anak usia dini pada dasarnya menyukai bentuk gambar dan warna yang menarik. Manfaat bermain puzzle menurut Crist (Yulianti, 2010:85), antara lain; mengasah otak, melatih koordinasi mata dantangan, melatih nalar, melatih kesabaran, danpengetahuan. Adapun jenis-jenis puzzle menurut Misbah (dalam Pramunda, 2016: 16-18), adalah sebagai berikut:

\section{Logic Puzzle}

Logic Puzzle adalah puzzle yang menggunakan logika berpikir. Seperti permainan teka teki silang, grid puzzle, tic toc, dan Sudoku. 


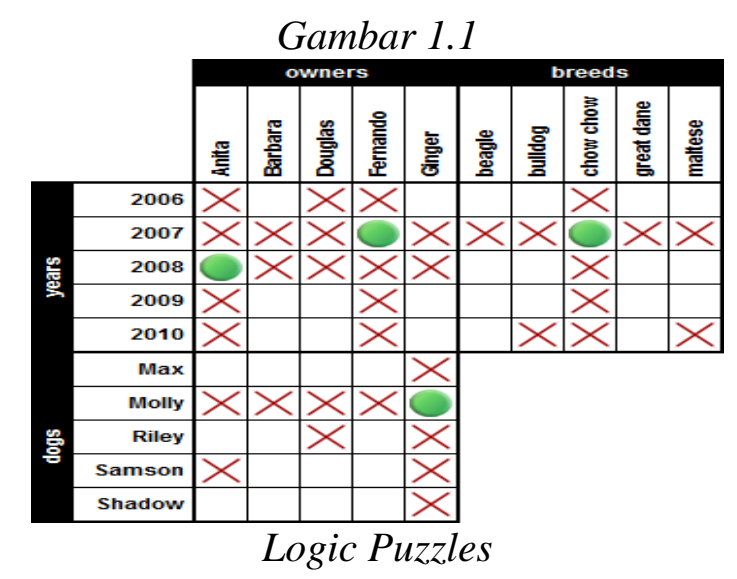

2. Combination Puzzle

Combination puzzle adalah puzzle yang dapat diselesaikan melalui beberapa kombinasi yang berbeda. Puzzle ini biasanya terbuat dari plastik atau kayu. Contoh combination puzzle adalah rubik cube dan chungky puzzle.

Gambar 1.2

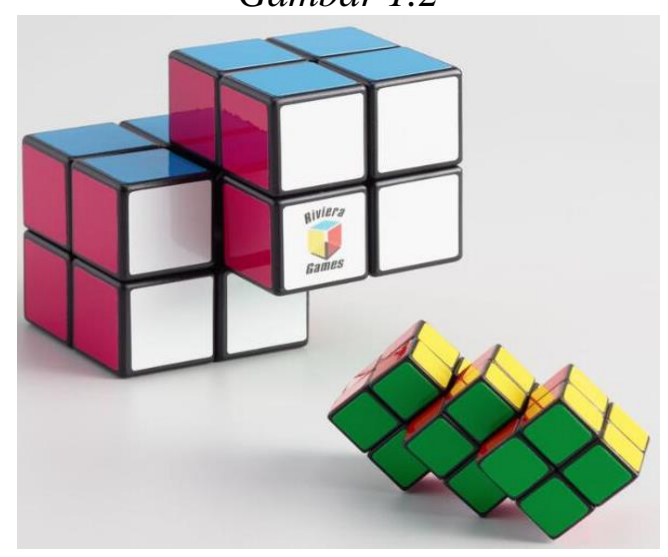

Rubik Cube

\section{Mechanical Puzzle}

Mechanical Puzzle adalah puzzle yang kepingnya saling berhubungan dan dapat membentuk suatu formasi. Contoh puzzle mechanical adalah mainan lego dan tetris kubus.

Gambar 1.3

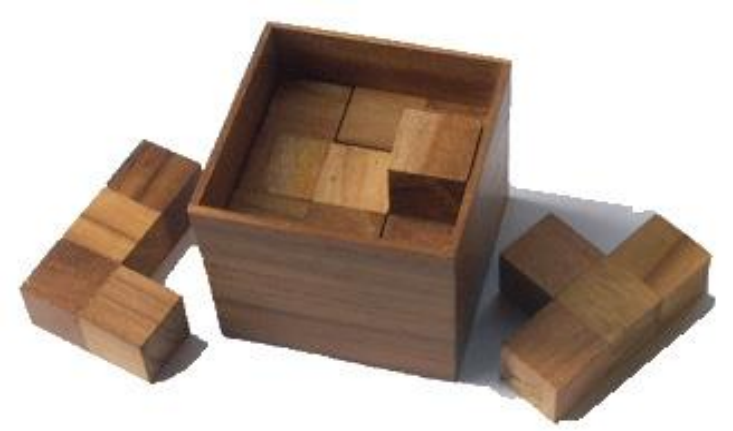

Tetris Kubus

4. Construction Puzzle

Puzzle konstruksi merupakan kumpulan potongan-potongan yang terpisah, yang dapat digabungkan kembali menjadi beberapa model. Mainan construction puzzle yang paling 
umum adalah blok-blok kayu berwarna-warni. Mainan rakitan ini sesuai untuk anak yang suka bekerja dengan tangan, suka memecahkan puzzle, dan suka berimajinasi. Contoh puzzle ini adalah mainan city block dan mainan kayu rainbow block.

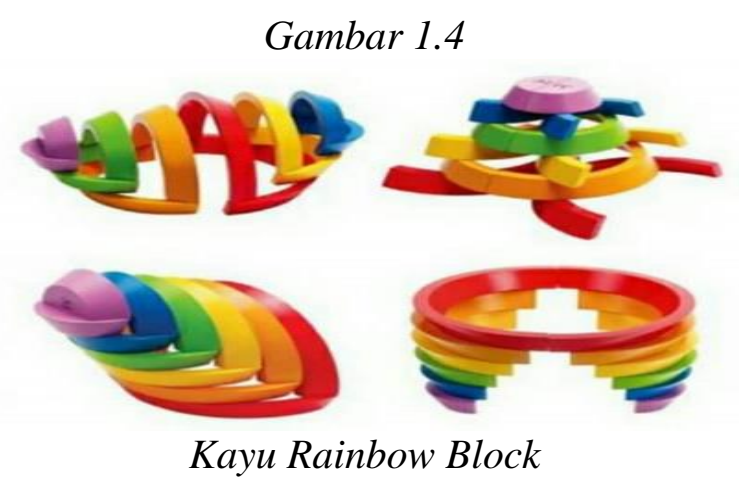

\section{Jigsaw Puzzle}

Jigsaw Puzzle adalah puzzle yang berupa kepingan gambar. Puzzle inilah yang umumnya banyak dimainkan dan digemari oleh anak-anak. Jigsaw puzzle inilah yang umumnya diketahui oleh sebagian besar orang. Bahan pembuat puzzle ini umumnya dari kayu atau MDF. Contoh jigsaw puzzle adalah tangram, puzzle huruf angka, puzzle hewan/binatang, puzzle buah sayur, puzzle matematika.

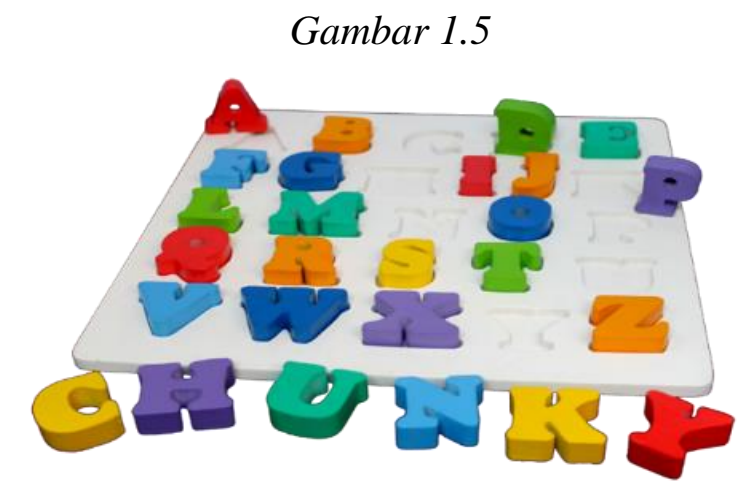

Puzzle Chunky Alphabet

Jigsaw sebagaimana penjelesan sebelumnya termasuk dari beberapa jenis puzzle, yang kerap digunakan diberbagai kegiatan pembelajaran anak usia dini. Model pembelajaran jigsaw dengan permainan puzzle adalah suatu metode pembelajaran yang menyusun potongan-potongan gambar yang telah disesuaikan dengan mal sehingga membentuk sebuah gambar yang benar serta menjawab pertanyaan yang sesuai dengan kode puzzle yang telah disusun (Wardani, NS Wardani, 2012:7). APE puzzle jigsaw terdiri dari beragam bentuk dan kegunaan akibat pengembangan oleh para pakar dan pendidik disesuaikan dengan kebutuhan.

Puzzle jigsaw dengan model alphabet adalah wujud nyata dari keragaman bentuk akibat pengembangan sebagaimana yang dimaksud. Berikut adalah contoh Puzzle jigsaw dengan model alphabet;

Gambar 1.6 


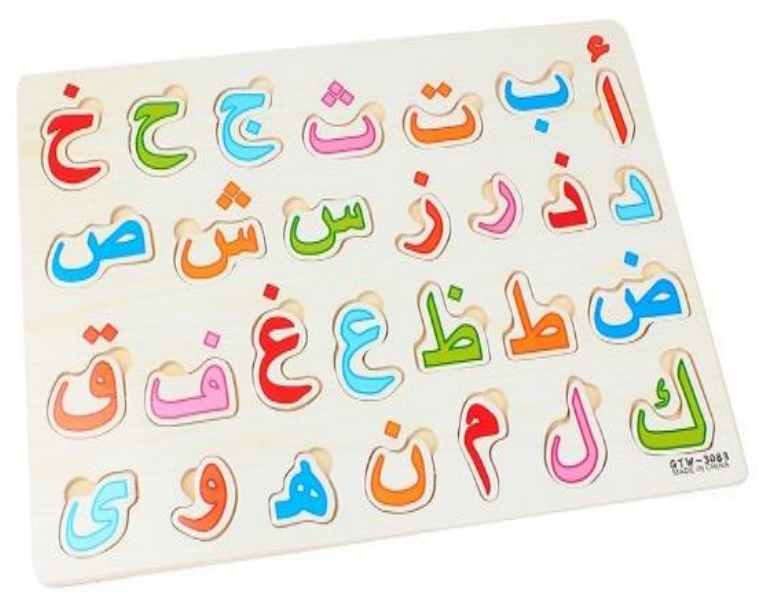

Puzzle alphabet huruf hijaiyah

Puzzle jigsaw dengan model alphabet arab ini lah yang nantinya akan peneliti gunakan sebagai media pemainan edukatif atau APE untuk meningkatkan minat belajar anak terhadap agama, sebagaimana yang telah dijelaskan sebelumnya akan penting pendidikan agama untuk anak usia dini. Pembelajaran anak usia dini dengan prinsip bermain dan belajar tentunya akan lebih optimal tatkala minat belajar peserta didik dalam hal ini anak usia dini juga tinggi.

Anak usia dini sebagai siswa menurut Slameto (2003: 57), terlihat minatnya dalam belajar ketika;

1. Memiliki kecenderungan yang tetap untuk memperhatikan dan mengenang sesuatu yang dipelajari secara terus-menerus.

2. Ada rasa suka dan senang terhadap sesuatu yang diminatinya.

3. Memperoleh sesuatu kebanggaan dan kepuasan pada suatu yang diminati.

4. Lebih menyukai hal yang lebih menjadi minatnya daripada hal yang lainnya.

5. Dimanifestasikan melalui partisipasi pada aktivitas dan kegiatan.

Pentingnya peranan minat dalam kesuksesan belajar merupakan dasar untuk kemudian dijadikan dasar untuk mengangkatnya kedalam sebuah penelitian dengan judul "Pengaruh Media Jigsaw Puzzle Terhadap Minat Belajar Huruf Hijaiyah Anak Usia Dini”.

\section{METODE PENELITIAN}

Metode penelitian yang digunakan dalam penelitian adalah eksperimen (experimental research) yang menurut Sukmadinata, 2011:194), merupakan pendekatan penelitian kuantitatif yang paling penuh, dalam arti memenuhi semua persyaratan untuk menguji hubungan sebab akibat. Adapun rancangan penelitian yang digunakan adalah:

\section{Tabel 1.2}

\begin{tabular}{|l|l|l|l|}
\hline Group & Pretest score & Treatment & Posttest score \\
\hline Experimental group & 01 & $\mathrm{X}$ & 02 \\
\hline \multicolumn{4}{|c|}{ Treatment effects= (02-01) } \\
\hline O1 : Pre-test $\quad$ X & : Perlakuan \\
O2 & Post-test
\end{tabular}

Populasi subjek penelitian ini adalah seluruh peserta didik atau siswa kelas B di TK Aisyiyah Bustanul Athfal 6 Kota Surabaya (J1. Mulyorejo No.100, Mulyorejo Kota 
Surabaya, Jawa Timur) dengan jumlah keseluruhannya di kelas tersebut saat penelitian ini dilaksanakan berjumlah 39 siswa.

Perihal populasi sebagaimana dijelaskan oleh Arikunto (2013: 173), adalah keseluruhan dari subjek penelitian, adapun subjek penelitian ia menambahkan merupakan sesuatu yang sangat penting kedudukannya didalam penelitian, subjek harus ditata sebelum peneliti siap untuk mengumpulkan data. Prosedur penelitian nantinya akan diawali dengan melaksanakan observasi ke TK Aisyiyah Bustanul Athfal 6 Kota Surabaya, penyusunan instrument penelitian berupa lembar pengamatan dan menyiapkan perangkat pembelajaran berupa alat permainan edukat/media puzzle jigsaw.

Tahap pelaksanaan yaitu memberikan pre-test dengan melaksanakan pembelajaran dengan mengangkat materi tentang alphabet bahasa arab tanpa menggunakan media puzzle jigsaw, dilanjutkan keesokan harinya dengan mengangkat tema yang sama hanya saja dengan media dengan puzzle jigsaw (post-test). Kemudian tahap akhir merekap dan menganalisis data mengolah data yang telah diperoleh dari hasil test pengamatan dengan uji statistik yang sesuai, membuat kesimpulan dan menyusun laporan penelitian.

Teknik pengumpulan data yang nantinya akan digunakan, khususnya pada saat menjalankan prosedur penelitian yakni observasi dengan menggunakan instrumennya dalam bentuk lembar observasi. Sutrisno Hadi (dalam Sugiono 2014: 145), menjelaskan bahwasanya observasi merupakan suatu proses yang kompleks, suatu proses yang tersusun dari berbagai proses biologis dan psikologis. Dua diantara yang terpenting adalah proses-proses pengamatan dan ingatan. Dalam metode observasi ini, observasi dilakukan untuk mengetahui perbedaan minat belajar huruf hijaiyah, baik dengan menggunakan media (puzzle jigsaw) maupun tanpa media (puzzle jigsaw) pada siswa kelas B di TK Aisyiyah Bustanul Athfal 6 yang berusia kisaran 5-6 tahun. Teknik analisis data yang di gunakan penelitian ini terlebih dulu dilakuakan pengurjian normalitas data dengan mengunakan chi Square, uji homogenitas data, t-test, dan menggunakan normalized gain.

\section{HASIL DAN PEMBAHASAN}

Penelitian ini bertujuan untuk mendeskripsikan dan menganalisis efektifitas penggunaan media puzzle jigsaw terhadap minat belajar huruf hijaiyah pada siswa kelas B di TK Aisyiyah Bustanul Athfal 6 yang berusia kisaran 5-6 tahun. Jumlah sampel dalam penelitian kali ini 12 anak. Hasil dari sampel tersebut diperoleh data nilai pre-test dan post-test anak yang meliputi:

1. Skor hasil pemantuan minta belajar anak pada saat pembelajaran tanpa menggunakan media puzzle jigsaw

2. Skor hasil pemantuan minta belajar anak pada saat pembelajaran dengan menggunakan media puzzle jigsaw

Hasilnya, skor pre-test dan post-test anak dapat dilihat pada tabel berikut ini;

Tabel 1.3

\begin{tabular}{|c|c|c|}
\hline \multicolumn{3}{|c|}{$\begin{array}{c}\text { Hasil Pengolahan Nilai Pres-Test } \text { dan } \\
\text { Post-Test }\end{array}$} \\
\hline \multirow{2}{*}{ Keterangan } & \multicolumn{2}{|c|}{ Nilai } \\
\cline { 2 - 3 } & Pre-test & $\begin{array}{c}\text { Post- } \\
\text { test }\end{array}$ \\
\hline
\end{tabular}

Vol. 1 No. 1 / April 2018

IJAZ ARABI homepage: http://ejournal.uin-malang.ac.id/index.php/ijazarabi 


\begin{tabular}{|c|c|c|}
\hline Uji Normalitas $\left(\mathrm{X}^{2}\right)$ & 0,5285 & 1,56885 \\
\hline Rata-rata $(\mathrm{X})$ & 15,415 & 32,375 \\
\hline Standar Deviasi & 2,995 & 5,295 \\
\hline Uji Homogenitas & 1,56 & \\
\hline Uji Hipotesis & 9,133 & \\
\hline
\end{tabular}

Berangkat dari pengelolaan data diatas, dapat kita lihat peningkatan minat sebelum menggunakan maupun sesudah menggunakan media yang mana dalam hal ini adalah puzzle jigsaw. Adapun skor hasil pengamatan sebelum menggunakan media yaitu 15,415 dan sesudahnya setelah menggunakan media puzzle jigsaw yaitu 32,375. Selisih dari kedua skor terilhat cukup mencolok dengan 16,96 yang artinya terdapat peningkatan yang cukup signifikan.

Pada standar deviasi juga terlihat perbedaan yang pada saat pre-test 2,995 dan meningkat menjadi 5,295 setelahnya artinya pada saat post-test. Standar deviasi seperti kita ketahui bersama digunakan untuk menentukan bagaimana sebaran data dalam sampel, dan juga seberapa dekat titik data individu ke mean - nilai sampel. Peningkatan pre-test sebagaimana terlihat diatas, dengan demikian membutkikan sebaran terjadi lebih intens pada saat post-test.

Skor pre-test muncul sebagaimana pada table akibat analisis statistis parametris dengan dari data hasil rata-rata dan standar deviasi pre-test. Hasil pada uji normalitas nilai pretest diperoleh $X^{2}$ hitung sebesar 0,5285 . Karena $X^{2}{ }_{\text {hitung }}<X^{2}$ tabel, dengan demikian hasil pretest berdistribusi normal.

Selain skor pre-test, untuk mengetahui pada skor post-test minat belajar akibat dari penggunaan media puzzle jigsaw, maka data hasil rata-rata dan standar deviasi posttest dapat dianalisis melalui statistik parametris, dengan data setiap variabel yang akan dianalisis berdistribusi normal.

Uji normalitas menghasilkan skor post-test $X^{2}{ }_{\text {hitung }}$ sebesar 1,56885 dengan $X_{\text {tabel }}^{2}$ sebesar 7,815. Akibat $X^{2}$ hitung $<X^{2}$ tabel, maka hasil post-test berdistribusi normal.

Sedangkan pada uji homogenitas data pre-test dan post-test diperoleh $\mathrm{F}_{\text {hitung }}$ sebesar 1,56 dan $\mathrm{F}_{\text {tabel }}=5 \%$ dengan $\mathrm{dk}$ pembilang $11 \mathrm{dan} \mathrm{dk}$ penyebut 11 sebesar 2,82. Sehinggga diperoleh $F_{\text {hitung }}(1,56)<F_{\text {tabel }}(2,82)$, maka dinyatakan homogen

Selain itu, guna mengetahui peningkatan minat belajar huruf hijaiyah akibat dari penggunaan media puzzle jigsaw rumus kuadrat deviasi diperoleh thitung 9,133 dan $t_{\text {tabel }}$ $(\alpha=5 \%$ dan $\mathrm{dk}=12-1=11)$ sebesar 0,69745 . Dengan demikian mengingat $t_{\text {hitung }}(9,133)$ $>t_{\text {tabel }}(0,69745)$, maka $\mathrm{H}_{\mathrm{a}}$ diterima dan $\mathrm{H}_{\mathrm{o}}$ ditolak.

Kondisi minat belajar anak khususnya dalam mengenal huruf hijaiyah di TK Aisyiyah Bustanul Athfal 6 Kota Surabaya sebelum dipergunakannya alat permainan eduaktif dalam bentuk media puzzle jigsaw sangatlah rendah. Hal itu dibuktikan dengan skor akumulatif hasil pengamatan yang rata-rata hanya 15,415 .

Fakta berbanding terbalik pada saat post-test yang mana setelah menggunakan media puzzle jigsaw, minat belajar huruf hijaiyah di TK tersebut meningkat menjadi ratarata 1,56885 . Berangkat dari fakta kuantitatif tersebut, tentunya dapat kita amini tatkala manfaat media puzzle sebagaimana yang dikemukakan oleh D. Yulianti melalui hasil penelitiannya terhadap pembelajaran fisika kontekstual (2010:89), yang menyatakan bahwasanya media puzzle jigsaw mampu memberikan beberapa manfaat yang diantaranya mampu meningkatkan minat dan hasil belajar siswa, tercapai. Dengan meningkatnya minat belajar, akan memudahkan pendidik tentunya dalam upayanya mentransfer beragam materi termasuk dalam kasus ini menyangkut dengan pengenalan 
huruf hijaiyah. Capaian pembelajaran yang sebelumnya telah direncanakan tentunya juga akan mudah tercapai.

Penggunaan media puzzle jigsaw yang kemudian mampu meningkatkan minat dan hasil belajar tidaklah suatu hal yang berlebihan, mengingat seperti yang pernah dikemukakan oleh Crist (Yulianti, 2010:85), menjelaskan lebih lanjut bahwasanya manfaat dari antara lain;

1. Mengasah otak

2. Melatih koordinasi mata dantangan

3. Melatih nalar

4. Melatih kesabaran dan pengetahuan.

\section{E. KESIMPULAN}

Pendidikan anak usia memegang peranan penting terutama dalam upaya menanamkan kecintaan dan pengenalan agama pada anak usia dini sebagai peserta didik. Hal ini dapat dilaksanakan dengan mudah, seperti penyajian permainan tentang kosakata dan huruf Arab. Dengan demikian, proses penanaman agama akan lebih konstruktif dan sistematis. Pada konteks pendidikan anak usia dini, diperlukan kemampuan pendidik yang ekstra dalam upayanya menanamkan pendidikan agama khususnya dalam contoh kasus penelitian kali ini yakni huruf hijaiyah.

Kemampuan dalam mengahdirkan dan menggunakan media yang efektif guna meningkatkan minat belajar pada anak juga perlu dimiliki. Hal ini terbukti dengan meningkatkan minat belajar pada anak dalam mempelajari huruf hijaiyah sebagaimana yang dihasilkan dalam penelitian kali ini di TK Aisyiyah Bustanul Athfal 6 Kota Surabaya. Terlihat peningkatan yang cukup signifikan terhadap minat belajar yang kemudian berimbas pada antusias dan hasil belajar yang lebih cepat tercapai jika disbanding tanpa menggunakan media yang dalam penelitian kali ini adalah puzzle jigsaw.

\section{REFERENSI}

Abdul Majid, dkk. (2005). Pendidikan Agama Islam Berbasis Kompetensi. (Bandung: Remaja Rosdakarya.

Arikunto, S. (2013). Prosedur Penelitian: Suatu Pendekatan Praktik. Jakarta: Rineka Cipta.

Badru Zaman, Asep Hery Hernawan dan cucu Eliyawati. (2007). Media dan Sumber Belajar TK. Jakarta: Universitas Terbuka.

Hidayat, Febri. (2013). Skripsi. Perancangan Game Edukasi Puzzle sebagai Media Pembelajaran Untuk Anak Usia Dini. Bandung: Universitas Komputer Indonesia

Mujib Fathul dan Nailur Rahmawati. (2013). Permainan Edukatif Pendukung Pembelajaran Bahasa Arab (2). Diva press: Yogyakarta.

Shofiatun A Rahman. (2010). Alat Permainan Edukatif Untuk Program PAUD. Palu: Tadulako University Press.

Slamet Suyanto. (2005). Dasar-dasar Pendidikan Anak Usia Dini. Yogyakarta: Hikayat Publishing.

Slameto. (2003). Belajar dan Faktor-faktor yang Mempengaruhinya. Jakarta: Rineka Cipta.

Sugiyono. (2014). Metode Penelitian Kuantitatif, Kualitatif dan R\&D. Bandung: Alfabeta. 
Sukmadinata, N.S. (2011). Metode Penelitian Pendidikan. Bandung: Remaja Rosadakarya.

Trianto. (2011). Model-model pembelajaran inovatif berorientasi konstruktivitis. Jakarta: Prestasi Pustaka.

Wardani, Naniek Sulistya. (2012). Pengaruh Pendidikan Karakter Pada Pembelajaran Tematik.Salatiga: Universitas Kristen Satyawacana.

Yulianti, D. (2010). Penerapan dalam Pembelajaran Kontekstual untuk meningkatkan Minat Dan Hasil Belajar Fisika Siswa SMP. Semarang: PFI Unnes.

Yulianti, Dwi. (2010). Bermain Sambil Belajar Sains di Taman Kanak-kanak. Jakarta: PT Indeks. 